\title{
猃 壇
}

\section{勤め続ける\&再出発のための 10力条}

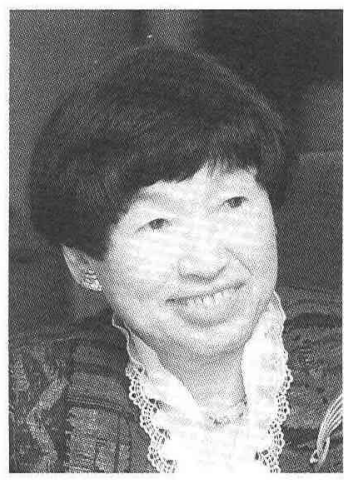

島田 淳子

\section{はじめに}

この3月に、30数年間勤めたお茶の水女子大学を 定年退職した。助手として人った調理学研究室は、 調理に打ける諸現象を科学の目で明らかにするこ とを目指す新設研究室であった。その当時は、調 理はカンやコッに頼るものとの風潮がまだまだ強 く、学問も確立していなかった。しかし、調理の 科学は、時代のニーズもあって急速に進歩し、 1968年に研究会として発足した日本調理科学会は、 現在では会員2000 余名を擁する学術会議登録団体 として活発な活動を展開している。めざましい発 展の中心となった研究室に長年在籍し、その一翼
を担えたことは幸せであった。

ところで本稿は調理科学とは関係ない。3月に行 つた最終講義の最後のスライド（別表）を中心に、 若い皆さんへのエールを送りたい。

初めに、最終講義にこのような内容を盛り込ん だいきさつを述べる。在職中数多くの卒業生を出 した。そのほとんどが社会に出て初めて、男性社 会の壁の厚さを実感する。有形無形の差別に苦し みながら働き続けても、出産、育児となると別の 苦しみや悩みが生ずる。真面目な学生ほど、ひと すじに悩む。こんな時ちょっと気を抜いて一歩退 き、まったく他の角度から眺めると、思いがけな い道が拓ける（もっともこれは研究についても言 


\section{論 壇}

えることだが)。一人で悩まないで、母校に相談に きてほしい。これを卒業生への言葉としてきた。 幸い私の所属した学科には、女性教官をはじめ、 様々な経歴をもつ女性の研究者あるいは穴の予備 軍がかなりおり、体験からくるアドバイスには事 欠かなかった。皆で行ってきたアドバイスを最後 のスライドにまとめ、最終講義に集まって下さっ た若い皆さんへの餞とした次第である。

\section{「大変なことは同時にやってくる」}

まず基本。不思議なことに、大変なことは同時 にやってくる。必ずといってよいほど重なる。で も、このことを知っていれば驚かない。迎え撃と う。がんばちう。そしてこれを乗り切った時、グ レードアップした自分を発見できる。

\section{「仕事のストレスは、声を立てて追い払う」}

仕事のストレスを家までもち帰らないのが、勤 めを続けるコッ。ストレスは帰宅の途中で追い払 おう。このためには、“声に出す”のが有効である。 特に大声のほうが有効（ただし、場所を必要とす る)。

\section{「スイッチの切り替えはすばやく」}

2 と似たような内容にみえるが、生まれたばかり の幼いわが子を残して働くことに、後ろめたさを
感じている若い母へのアドバイスである。朝、今 日一日のわが子の保育に関して万全の措置をした ら、スイッチをすばやく仕事モードに切り替えよ う。わが子の体調が悪いからといって、心配して いても始まらない。自分の措置に自信をもち、仕 事に打ち込む。終わったらスイッチをすばやく切 り替えればよい。

\section{「スキンシップの不足は、} 時間 $x$ 濃度でカバー」

しかし、わが子とのスキンシップが不足する。 特に、根強い3歳児神話などが母親の不安を増幅さ せる。時間の不足は濃度でカバーしよう。帰宅後 の子供との濃密なひとときは、時間の不足を十分 に補ってくれる。このひととき、散らかった家が 気になる。でも、ほこりでは死なない、と心に念 じて、ゆったりした時間をもとう。

\section{「子供の後追いは、ほんのいつとき」}

こうしてしばらくもちこたえた所にやってくる のが、子供の後追いである。かわいいわが子が自 分の後を追って泣く。これを振り切って勤めに行 くのは、母親にとって相当こたえる。こらえ切れ ずに勤めを辞めてしまった卒業生が何人かいる。

しかし、後追いは子供の成長の一過程であり、 後になってみるとほんのいっときである。しかも、 
子供が親の愛情を十分に感じていれば、後には全 然残らないから安心してほしい。

ただし、愛していればそれで良いのではない。 子供のほうで、親にたっぷり愛されていると感じ なくてはいけない。同じように接しても、子供に よって十分満足する子もいれば、不足を感じる子 もいる。子供の特性を見抜いて、それぞれが十分 愛されていると感じるよう、愛情表現を工夫する 賢さが必要。

\section{「疲れ過ぎは禁物・上手に手を抜く」}

子育てと仕事の両立はなんと言っても大変。疲 れる。でも、疲れ過ぎは禁物。ポキッと折れてし まうことがある。些細な夫婦喧嘩の原因にもなる。 上手に手を抜くコツを会得しよう。もちろん手抜 きは平気の無責任人間になれ、というのではない。 手抜きの苦手な、真面目で誠実な優等生の皆さん に特に薦めてきた言葉である。

\section{「低空飛行でもかまわない、 墜落しなければ」}

それでもストレスがたまる。私自身の経験から 言うと、実験がうまく行って、もう少し続けたい、 もう少し続ければずいぶん能率が良いのがわかっ ているのに、終わりにしなければいけないのが残 念でストレスになった。その時救われたのが、こ
の言葉である。30年ほど前だろうか、来日したイ ギリスのノーベル化学賞受賞者 D.C. Hodgkin女 史（記憶があいまいで自信はないが）が、ご自分 の20代の経験から、この言葉を日本の若い女性科 学者へのメッセージとして下さったのである。肩 の力を抜いて、気分転換し、希望をもって仕事を 続けられる言葉である。私たちも、この言葉をず いぶん使わせていただいた。

\section{「今日一日だけはがんばろう」}

それでも、続けられそうもなくなったら、この 言葉が登場する。先のことは一切考えなくて良い。 とにかく今日一日だけはがんばろう。それも無理 だったらまたいらっしゃい、ということにしてお いたら、続いてしまった人が何人かいる。意外な 効き目に皆で驚いたことがある。

\section{「再出発に年齢はノーカウント、 人と比較はしない」}

しかし、最初の仕事を続けるだけが能ではない。 方向転換して再出発する人もたくさんいる。こん な時に必要な心構えが、この言葉である。人と比 較しない。自分の昨日と比較しよう。昨日より一 歩でも半歩でも前進していれば良しとしよう。 


\section{論 壇}

\section{「ネットワークを利用しよう」}

最後は一人で思い詰めないこと。ネットワーク の利用が下手な後輩たちに、もどかしさを込めて のアドバイスである。

\section{子育てには喜びと感動がある}

振り返ってみると、仕事と、家事と、育児に悪 戦苦闘している人たちへのアドバイスが多い。以 前はほとんどの学生が、卒業後 2 ～年すると結 婚し、出産したからである。しかし、わが母校に も結婚の高齢化、非婚女性の増加は確実に押し寄 せている。仕事、特に研究に没頭する充実感を味 わってしまうと、結婚や出産など考えられなくな る気持ちは、私にも十二分に理解できる。

しかし、複雑な一つの生命がすごいスピードで (知識の獲得、研究成果の蓄積などとは比べようも ない速さで）成長していくのを自分の体で実感で きるのは、なんといっても感動である。

日本社会がまだまだ男性社会であることは認め るが、以前に比べたらずいぶん良くなっている。 若い皆さんには、仕事だけでなく男性・女性で力 を合わせて次世代をはぐくみ育てる喜びを味わつ てほしい。子育てには、苦労を補って余りある喜 びと感動があるのだから。

本誌の大方の読者の方々は、こんなアドバイス
とは無縁の世界に生きていらしたことと思う。し かし、皆様のまわりにきっといるであろう若い女 性たち一悩んだり、迷ったりしながら孤独の中で がんばっているであろう若い女性たち一に対する ご支援の一助としていただけたら幸いである。皆 様方のご理解とご支援こそ、少子化抑制の大きな 力であるゆえ。

\section{勤め続ける\&再出発のための10力条}

1. 大変なことは同時にやってくる

2. 仕事のストレスは、声を立てて追い払う

3. スイッチの切り替えはすばやく

4.スキンシップの不足は、時間 $x$ 濃度で カバー

5. 子供の後追いは、ほんのいっとき

6. 疲れ過ぎは禁物・上手に手を抜く

7. 低空飛行でもかまわない、墜落しなければ

8. 今日一日だけはがんばろう

9. 再出発に年齢はノーカウント、人と比較 はしない

10、ネットワークを利用しよう

島田＼cjkstart淳子（しまだ あつこ 1933年生）

昭和女子大学大学院生活機構研究科教授、お茶の水女子大学名誉 教授

専門: 家政学、調理科学 